\title{
Pemeliharaan Anak Dalam Perspektif Fiqh dan Hukum Positif
}

\section{Rohidin}

\section{Abstrak}

Basically, there is no disticntion on classic Figh, on law of the Republic of Indonesia Number 1 of the year 1974 on Marriage, and Islamic Law Compilation relate to children care right. The distinction is merely on the determination of age limit of mumayyiz. When divorce occurs, children before 12 years old (before mumayyis) is to be the right of the mother or a close relative to the mother, while the cost of bringing up the children will be the responsibility of the father. In a particular condition, the children care right may move to the father. Even, on Act No. 1/ 1974 states that the right of one of the parents can be withdrew if one or both of the parents neglect their duties and perform extremely bad behaviour.

\section{Pendahuluan}

Perkawinan adalah sesuatu yang sakral, bahkan umat Islam menganggapnya sebagai ibadah. Perkawinan adalah sesuatu yang amat penting bagi kehidupan kita termasuk kehidupan agama. Karena itu umat Islam di Indonesia ingin agar perkawinan itu sah menurut hukum agama dan sah menunut hukum negara. Untuk tujuan itu, sejak akhir 1950-an semua parpol Islam memperjuangkan lahirnya UU yang mengakomodasi syariat Islam yang partikular dalam masalah perkawinan. Tetapi perjuangan itu tidak berhasil.

Pada tahun 1973 Fraksi Karya Pembangunan (FKP) mengajukan RUU Perkawinan yang sama sekali mengabaikan syariat Islam. Tentu parpol dan ormas Islam menolak RUU yang bertentangan dengan syariat Islam itu. Berkat perjuangan para tokoh Islam untuk meyakinkan Presiden Soeharto, akhirnya pasal-pasal yang bertentangan dengan syariat Islam dihilangkan. Maka UU No 1 Tahun 1974 tentang Perkawinan menjadi UU pertama yang mengandung ketentuan partikular syariat Islam.

Selanjutnya, lahirlah Instruksi Presiden No 1 Tahun 1991 tentang penyebarluasan Kompilasi Hukum Islam (KHI). Di dalam KHI ada tiga bidang hukum Islam yakni hukum perkawinan (munaakahat), hukum kewarisan (mawaarits), dan hukum perwakafan (waqf) yang menjadi pedoman bagi hakim agama dalam memutuskan perkara dan juga menjadi pedoman bagi umat Islam dalam mengamalkan hukum Islam pada tiga bidang tersebut.'

Perkawinan yang bersifat sakral dan bertujuan luhur tersebut terkadang dalam

1 Salahuddin Wahid "Perkawinan, Agama, dan Negara" http://www.republika.co.id/koran detail.asp., diakses tanggal 09 Juni 2005. 
realita tidak dapat dipertahankan selamanya, dari waktu ke waktu, kasus perceraian tampaknya terus meningkat. Maraknya tayangan infotaiment di televisi yang menyiarkan parade artis dan public figure yang mengakhiri perkawinan mereka melalui meja pengadilan, seakan mengesahkan bahwa perceraian merupakan tren. Sepertinya kesakralan dan makna perkawinan sudah tidak lagi berarti. Pasangan yang akan bercerai sibuk mencari pembenaran akan keputusan mereka untuk berpisah. Mereka tidak lagi mempertimbangkan bahwa ada yang bakal sangat menderita dengan keputusan tersebut, yaitu anak-anak. ${ }^{2}$

Banyaknya kasus penderitaan yang dialami oleh anak-anak akibat perceraian orang tuanya, baik di Indonesia maupun di negara-negara lain, menunjukkan betapa pentingnya aturan tentang pemeliharaan anak setelah perceraian. Karena tanpa adanya aturan tentang hal ini, akan mengakibatkan munculnya berbagai tindakan, bahkan tidak terkecuali tindakan kriminal seperti penculikan anak oleh pihak-pihak tertentu yang merasa haknya dirampas oleh orang lain baik itu saudara, maupun mantan saudara bahan mantan suami atau istri.

Satu contoh kasus yang pernah térjadi di Malaysia, di mana antara kakak dan adik berulangkali berperkara baik ke Pengadilan Syariah, Pengadilan Sipil bahkan ke Kepolisian, untuk masalah penerbitan hak mengasuh seorang anak. Peristiwanya dimulai ketika si ibu mengalami kalainan dalam persalinan yang dilakukan dengan operasi. Ketika si ibu harus dirawat di rumah sakit untuk berobat kembali bekas operasinya, terpaksa si anak dititipkan sementara kepada adiknya yang sudah berkeluarga tetapi belum mempunyai keturunan tanpa adanya perjanjian adopsi. Begitu sang lbu sembuh, ternyata si anak sudah telanjur mapan dan terkondisikan dalam keluarga saudara ibunya. Ujungnya orang tuanya tidak terpenuhi keinginannya untuk mendidik anak tersebut seperti kepada anak-anaknya yang terdahulu, lantaran si anak menurut orang tuanya sudah berperangai tidak baik akibat kebiasaan dalam keluarga adiknya.

Karena kesimpulan orang tua terhadap si anak demikian, maka tindakan orang tua tersebut menjadi lebih keras terhadap si anak dalam hal pendidikan, disiplin dan berperilaku dalam hubungan sosial. Tetapi tindakan tersebut justru menjadikan si anak merasa tidak nyaman di rumah orang tuanya sendiri dan memilih ikut orang tua asuhnya yakni bibinya. Dari sinilah mulai timbul banyak tindakan hukum yang melibatkan kedua keluarga kakak beradik itu. ${ }^{3}$

Kasus lain seperti yang terjadi pada Pak Edy (bukan nama sesungguhnya), yang berprofesi sebagail dosen, mengalami kesulitan untuk mengasuh anak satu-satunya yang beirusia empat tahun. Anaknya menjadi sangat nakal dan tidak mau ửitingygal- hokoria oleh ayahnya semenjak Pak Edy berpisah dengan istrinya.

Ayu, anak berumur delapan tahun, mengalami perubahan sangat memprihatinkan setelah orang tuanya bercerai. la tidak mau

"M.MNilam Widyarini, "Derita Anak Korban Perceraian" http:/www.kompas.com/kesehatan/news/0503/ 18/110246.htm, diakses tanggal 09 Juni 2005.

${ }^{3}$ Kasus Azizah Shaik Ismail vs Fatimah Shaik Ismail "Judgment High Court of Malaya" www.jpsofactol.com/ highcourtindex.htm. diakses tanggal 20 Maret 2005. 
berangkat sekolah, sebab, di lingkungan dia belajar banyak temannya yang bertanya-tanya tentang kasus perceraian orang tuanya. ${ }^{4}$

Peristiwa lain yang mengenaskan kembali terjadi. Diduga karena harus memikul beban berat akibat perceraian orang tua, seorang bocah bernama Nazar Ali Julian (13 tahun.) mencoba bunuh diri dengan menusukkan pisau dapur ke perutnya. Anak malang itu adalah warga Ciwalen Pasar RT 04/02 Desa Ciwalen Kecamatan Sukaresmi Kabupaten Cianjur.

Bunuh diri yang dilakukan orang dewasa, sepanjang tidak berjumlah massal, dipandang sebagai peristiwa kegagalan kejiwaan dia sebagai individu dalam menghadapi realitas yang ada. Dia tidak dipandang sebagai gejala struktur sosial. Tetapi ketika kita membaca bahwa bunuh diri kini juga sudah dilakukan oleh kalangan anak-anak, maka terasa ada. sesuatu yang menyentuh. Setiap peristiwa tragis yang mengorbankan anak-anak, akan selalu meluluhkan hati keras kita untuk segera bertanya, ada apa gerangan?

Kita baca bahwa Nazar lahir dari keluarga broken home. Orangtuanya bercerai, kemudian ibunya menjadi tenaga kerja wanita (TKW) di Arab. Perceraian, kesulitan ekonomi, telah memerosokkan siswa kelas 1 SMP ke dalam keterasingan. Our house just ain't a home: Rumah baỹi dia bukanlah tempat tinggal. Begitulah, akhirnya. Anak rajin dan soleh ini akhirnya menghunjamkan pisau ke perutnya sendiri. Sebuah tindakan yang tidak boleh dilakukan siapapun, apalagi anak-anak. ${ }^{5}$
Contoh yang lain baik yang mirip dengan kasus di atas maupun yang berbeda cukup banyak, baik mengenai hak mengasuh anak dalam keluarga maupun pasca perceraian. Tentu persoalan hukum semacam ini sudah terjadi di masa-masa yang lampau sehingga sudah dirancang, oleh para ahli hukum saat itu, berbagai aturan dasar dalam hal pengelolaan hak mengasuh anak. Atas dasar asumsi inilah maka tulisan berikut akan berusaha menggali berbagai pandangan atau peraturan tentang pemeliharaan anak baik yang terdapat dalam literatur figh maupun menurut hukum positif tentang hal ini yang lebih populer dengan istilah Hadhanah.

\section{Anak dalam Perspektif Islam}

Hadhanah secara etimologis merupakan jenis kata turunan dari akar kata ha-dha-na yang arti asalnya adalah memeluk, mendekap atau mengerami telor untuk burung atau unggas. Ketika kata ini digunakan untuk orang maka berarti mengasuh atau memelihara dengan segala aspekya. Sedang secara terminologis para fukaha mendefinisikan istilah hadhanah sebagai merawat dan mendidik anak yang belum mumayyiz (belum dewasa) atau yang kehilngan kecerdasannya, karena mereka tidak dapat memenuhi keperluannya . sendiri". ${ }^{6}$ Merawat artinya memelihara dan menjaga kepentingan anak serta melindunginya dari segala yang membahayakan dirinya. Mendidik artinya membekali anak dengan pengetahuan rohani

${ }^{4}$ M.M Nilam Widyarini, M.Si, "Derita Anak Korban Perceraian" http://www.kompas.com/kesehatan/news/ 0.503/18/110246.htm, diakses tanggal 09 Juni 2005.

${ }^{5}$ Pikiran Rakyat, "Doa untuk Nizar Ali", 17 Pebruari 2004.

${ }^{6}$ Abdul Azis Dahlan, Ensiklopedi Hukum Islam, (Jakarta: Ikhtiar Baru, 1999), hlm. 415. 
dan jasmani serta akalnya, supaya si anak dapat berkembang dan dapat mengatasi persoalan hidup yang akan dihadapinya. Belum mumayyiz maksudnya si anak baik lakilaki atau perempuan yang masih kecil belum dapat berdikari dan belum memiliki kecerdasan atau pengetahuan yang cukup sehingga karenanya si anak belum dapat memenuhi kebutuhannya sendiri.

Dengan demikian hadlanah mencakup berbagai aturan hukum berkenaan dengan anak dalam hal memenuhi hak hidupnya, keamanan, kecerdasan, maupun kebutuhan mental dan fisiknya. Aturan demikian diarahkan untuk menentukan kriteria anak, usianya, dan siapa yang berhak untuk mengasuh dan mendidiknya baik sewaktu dalam perkawinan maupun setelah terjadi perceraian. Munculnya hak ini tentu bermula dari kelahiran si anak apakah anak ini lahir dalam perkawinan dan di luar perkawinan. Karena itulah tulisan ini akan memulai pembicaraannya tentang anak dan kriterianya terlebih dahulu.

Pada dasarnya Islam hanya mengajarkan bahwa hubungan seorang laki-laki dengan perempuan yang dapat berakibat lahirnya seorang anak dianggap sah apabila hubungan tersebut terjadi dalam pernikahan. Tetapi karena fakta historis menunjukkan adanya hubungan yang sah maupun yang tidak sah (di luar nikah), maka Islam mengenal tipologi anak dalam tiga kategori, yakni anak (sah), anak zina, dan anak li'an. Anak yang terlahir ke dunia dianggap menjadi anak sah yakni memiliki hubungan nasab, dengan segala konsekuensi hukumnya, dengan ibu dan bapaknya, kalau anak itu lahir sebagai hasil hubungan suami istri dalam perkawinan. Anak zina adalah anak yang dilahirkan ibunya sebagai akibat dari hubungan yang tidak sah (terjadi di luar nikah). Sedangkan anak li'an adalah anak yang secara hukum tidak dinasabkan kepada bapaknya, setelah suami istri saling me-li'an dengan sifat tuduhan yang jelas. ${ }^{7}$ Dengan demikian tipe anak yang terakhir secara hukum dinasabkan hanya kepada ibunya.

Masing-masing dari ketiga jenis status anak di atas pada gilirannya berpengaruh dalam masalah hak mengasuhan. Untuk anak zina sebagai anak yang lahir dan hanya memiliki hubungan nasab dengan ibunya saja tidak dengan ayahnya, oleh karenanya hak mengasuhnya kembali pada si ibu. Sedang anak li'an meskipun ia lahir dalam suatu perkawinan, tetapi karena alasan hukum, sang suami mengingkari kesahan anak yang lahir tersebut sebagai anaknya. Alasan hukum yang dimaksud adalah jika si istri setelah pernikahan melahirkan anak dengan masa kehamilan di bawah batas minimal masa kehamilan setelah perceraian. Anak li'an semacam ini jika jelas terbukti tuduhan si suami maka meskipun si anak lahir dalam perkawinan yang sah, ia hanya memiliki hubungan nasab dengan ibunya saja.

Sedangkan status anak yang menjadi' wacana dalam ketentuan hukum hadhanah adalah anak yang memiliki status sah. Dalam pandangan fiqh anak sah adalah anak yang masa konsepsinya dalam rahim seorang ibu, yakni terjadinya pembuahan sel telur oleh sperma seorang bapak, terjadi dalam

7Fathurrahman Djamil, "Pengkuan Anak Luar Nikah dan Akibat Hukumnya" dalam Chuzaimah T. Yanggo dan HatizAnshar, Problematika Hukum Islam Kontemporer, (Jakarta: Firdaus, 2002), hlm. 104. 
perkawinan yang sah. Dengan demikian anak yang dapat dianggap sebagai anak sah (yang dibicarakan hak asuhnya dalam figh) adalah anak yang lahir sekurang-kurangnya enam bulan sesudah pernikahan atau di dalam tenggang waktu iddah selama empat bulan sepuluh hari sesudah perkawinan terputus. ${ }^{8}$ Anak semacam ini menurut figh, memiliki hubungan nasab dengan ibu dan bapaknya.

\section{Hak Asuh Anak dalam Perkawinan}

Pada dasarnya, semua ahli fiqh sepakat bahwa merawat dan mendidik anak merupakan suatu kewajiban. Mereka berbeda pendapat tentang hak siapa hadhanah ini. Ada yang berpendapat bahwa hadhanah adalah hak bersama antara orang tua (ibu dan ayah) dengan anak. Dengan pendapat pertama, maka dimungkinkan si ibu menggugurkan haknya. Kalau ini terjadi maka kepentingan anak menjadi tidak terpenuhi. Atau dengan kata lain jika hadhanah hanya menjadi hak ibu dan kebutuhan si ibu melepaskan hak tersebut maka si anak dapat telantar. Karena itulah maka, jumhur (kebanyakan ulama) berpendapat bahwa hadhanah merupakan hak bersama antara kedua orang tua dan anak. Kalau salah satu pihak orang melepas haknya, maka si anak dapat menuntut terpenuhi hakhaknya, sehingga orang tua tetap bertanggungjawab atas anaknya dalam semua kebutuhan asasinya baik kebutuhan ekonomi, pendidikan ataupun kasih sayang. Terkecuali jika ada alat tertentu yang menghalangi terlaksananya hak hadhanah bagi orang tua, maka orang tua dapat melimpahkan hak itu pada orang lain baik secara temporal maupun permanen. Tetapi ini hanya satu bentuk pengecualian atau ekspresi, jadi bukan satu prinsip dasar.

Islam pada prinsipnya menyerahkan tanggung jawab mengasuh, memelihara dan mendidik anak kepada orang tua. Orang tua menurut Islam juga bertanggungjawab untuk mengawasi, melindungi, dan memberi pelayanan yang layak serta mencukupi kebutuhan anak. Tanggung jawab ini bersifat permanen dan berkelanjutan hingga si anak mencapai batas usia hukum sebagai orang yang mampu memenuhi kebutuhannya sendiri. ${ }^{9}$

Islam mengajarkan tentang tanggung jawab orang tua terhadap anak di samping yang bersifat material, juga mengajarkan bahwa orang tua bertanggung jawab membekali anak dengan pengetahuan dan kecakapan yang berguna bagi anak setelah ia dapat berdiri sendiri di tengah masyarakat. Islam mengajarkan bahwa orang tua bertanggungjawab membekali anak dengan pelajaran aqidah, ibadah maupun akhlak yang benar. Jadi orang tua harus mengajarkan tauhid, syukur, berbuat baik pada orang tua, bergaul dengan orangtua secara ma'ruf, bahwa Allah pasti membalas setiap perbutatan manusia, melaksanakan shalat, amar ma'ruf nahi munkar, sabar, tidak sombong atau angkuh dan sederhana dalam tutur kata maupun bersikap. ${ }^{10}$ Orang tua juga harus

${ }^{8}$ Wirjono Rpodjodikoro, Hukum Perkawinan di Indonesia, (Bandung: Sumur, 1960), hlm. 72. Undangundang No. 1 Tahun 1974 tentang Perkawinan mengatur anak sah dalam Pasal 42, 43 dan 44. Pasal 42 berbunyi "Anak sah adalah anak yang dilahirkan dalam atau sebagai akibat perkawinan yang sah."

${ }^{9}$ M. Yahya Harahap, Hukum Perkawinan Nasional, (Medan: Zahir Trading, 1975), him. 204.

${ }^{10}$ Q.S. Lukman: 12-19. 
memberi bekal ketrampilan kepada anak, kalau tidak dapat melakukan sendiri, maka orang tua harus mengupayakan agar anak dapat memperoleh pendidikan dari orang lain tentang tata tulis, maupun ketrampilan fisik lainnya.

Demi terpenuhinya hak anak dari orang tuanya dalam keluarga, maka orang tua harus memikul bersama tanggung jawab ini dan saling kerjasama serta bantu-membantu antara ibu dan bapak. Islam memiliki konsep pernikahan sebagai media terciptanya keluarga yang sakinah, yang kondusif bagi terwujudnya tanggung jawab bersama di antara bapak dan ibu dalam mengelola dan menjalankan proses pemeliharaan dan pendidikan anak dalam keluarga.

\section{Hak Asuh Anak Selepas Perceraian}

Perceraian, meskipun dimungkinkan terjadinya, dalam figh sebenarnya termasuk peristiwa yang mestinya dihindari. Perceraian memang dihalalkan terjadinya, namun demikian ia masuk dalam kategori barang halal yang paling dibenci oleh Allah. "Kalaupun perceraian harus terjadi, maka dalam fiqh masih terdapat berbagai aturan hukum yang harus ditaati oleh seorang mantan suami atau istri baik yang berkaitan dengan asal harta, nafkah, juga aturan-aturan yang terkait dengan masalah anak.

Jika dalam perkawinan hak asuh anak menjadi hak bersama antara anak dan orang tua, lału bagaimana setelah orang tua dalam perkawinan itu bercerai. Para fukaha umumnya sepakat bahwa pada prinsipnya hak asuh anak dasarnya adalah untuk kemaslahatan anak. Dengan demikian meskipun terjadi perceraian antara seorang bapak dan ibu demi kemaslahatan umat, maka kedua orang tua itu sama-sama bertanggungjawab atas anaknya. Tetapi dengan pertimbangan berbagai hal, jika diperbandingkan antara bapak dan ibu dalam soal hak mengasuh anak, maka para ahli figh pada umumnya menyepakati untuk memberikan hak asuh itu kepada ibu dan keluarga pihak ibu jika si ibu berhalangan. ${ }^{12}$

Dasar ketentuan Fiqh ini adalah hadits yang menceritakan bahwa suatu saat datang seorang wanita kepada Rasullulah, kemudian bercerita bahwa ia adalah seorang ibu dari seorang anak dan dia diceraikan oleh suaminya tapi suaminya hendak mengambil anak itu dari tangannya. Rasullullah dalam hal ini memutuskan, hahwa si ibu lebih berhak menjaga anak itus ajui,si ibu belum menikah lagi dengan orang lain..13

"H. Badruzzaman Busyairi "Perceraian Halal tapi Dibenci Allah" http://muhajirien.or.id/mukaddimah/ buletin/mi edisi 110 htm, diakses tanggal 10 Juni 2005.

${ }^{12}$ Ketentuan ini sangat berbeda jika dibandingkan dengan hukum Romawi yang berpengaruh banyak terhadap hukum Perancis dan melalui hukum Belanda sampai ke Indonesia dan masuk ke dalam hukum Perdatar BW, anak-anak berada di bawah kekuasaan bapaknya. Semula kekuasaan ini (patria potestas) tidak terbatas; dan dapat dikatakan bahwa hidup dan matinya seorang anak berada dalam kekuasaan bapaknya. Lambat laun: kekuasaan ini menjadi berkurang, namun tetap saja masih besar dibanding dengan kekuasaan ibunya. Lihat Martiman Prodjohamidjodjo, "Hukum Perkawinan Indonesia" dalam Amiur Nuruddin, dan AzhariAkmal Tagiran, Hukum Perdata Islam di Indonesia, (Prenada Media, Jakarta, 2004), him. 292.

${ }^{13}$ Munira Salleh "Hak Penjagaan Atas Anak Selepas Perceraian: Tanggungjawab Siapa?" http:/l 
Bertolak dari hadits di atas, ada dua ketentuan fiqh tentang hadlanah, yakni pertama bahwa selepas perceraian ibu lebih berhak mendapat hak asuh anak, keduanya bahwa hak itu menjadi gugur manakala si ibu menikah lagi dengan lelaki lain. Berkaitan dengan hal pertama berarti kewajiban menanggung biaya mengasuh itu konsekuensinva jatuh pada pihak bapak. Kalau si ibu tidak menikah lagi maka proses pelaksanaan hak asuh ini terus berlanjut sampai si anak dipandang mumayyiz. Para ahli Figh umumnya menentukan bahwa mumayyiz anak jika laki-laki adalah umur tujuh tahun dan jika anak perempuan adalah umur sembilan tahun.

Jika anak itu sudah mumayyiz, ketentuannya adalah bahwa hak asuh itu kembali pada prinsip bahwa pelaksanaan hak asuh ini dasarnya adalah kepentingan atau kemaslahatan anak. Dalam hal ini demi menjaga kepentingan anak, maka anak yang sudah mumayyiz diberi kebebasan menentukan pilihan tentang hak asuhnya kepada ibu atau bapak.

Sedang jika syarat menerima hak asuh tidak terpenuhi oleh ibu, misalnya jika sebelum añấk itu mumayyiz si ibu sudah menikah lagi dengan orang lain, para ulama figh sependapat untuk melimpahkan hak itu pada keluarga pihak ibu misalnya, nenek pihak ibu ke atas. Dasar hukumnya adalah analogi (qiyas) dengan hadis di atas, bahwa pihak wanita lebih dekat pada anak sehingga hak hadlanah diutamakan jatuh pada ibu. Demikian pula kerabat ibu menjadi lebih berhak atas hak asuh ini dari pada kerabat bapak. Itulah mengapa jika hilang kelayakan ibu atas hak asuh anak, maka hak asuh anak itu jatuh pada kerabat pihak ibu. Pendapat ini juga dipegangi oleh Ibnu Qayim dan Sayid Sabiq. ${ }^{14}$ Dalam keadaan tertentu, menurut fiqh, kondisi di atas memang dapat berubah, tentu karena adanya alasan hukum menyangkut kepentingan anak misalnya setelah perceraian si istri harus bepergian jauh, jika ia harus bersama dengan anaknya yang masih kecil maka dimungkinkan akan membahayakan keselamatan anak.

Di beberapa negara dewasa ini memang terdapat berbagai model mengasuh anak setelah perceraian. Di Amerika misalnya, ada yang disebut dengan parents every day untuk ibu dan weekend parent untuk ayah. Untuk model ini hak asuh anak ada pada kedua orang tua yang sudah bercerai, hanya pembagian waktu yang bervariasi yakni anak selama satu minggu bersama ibu tapi pada tiap akhir pekan anak bersama bapak. Ada juga yang dibagi tiap minggu misalnya minggu pertama dan ketiga anak bersama ibu dan minggu kedua keempat anak bersama bapak. Contoh terakhir ini kadang memunculkan probiem baru bagi anak yang harus sekolah selama satu minggu dan akhir pekannya tidak dapat digunakan untuk istirahat karena anak pada hari itu harus pindah ke tempat orang tuanya yang lain yang

www.yadim.com.my/Keluarga/KeluargaFull.asp?Keluargal $D=78$ ", diakses tanggal $10 \mathrm{Juni}$ 2005. Hadis itu selengkapnya berbunyi diriwayatkan oleh Abdullah bin Umar: "Bahwasanya seseorang perempuan telah datang menemui Rasulullah saw dan bertanya: Ya Rasulullah, bahwa anakku ini, perutkulah kandungannya, susukulah minumannya dan ribaanku rumahnya tetapi bapanya telah menceraikan aku dan hendak merampas anak itu daripada aku'. Selepas mendengar pengaduan itu Rasulullah saw bersabda: "Engkaulah yang lebih berhak menjaga anak itu selagi engkau belum menikah lagi." (Riwayat Abu Daud).

${ }^{14}$ Sayid Sabiq, Figh Sunnah, VIl: 219. 
kebetulan tempatnya berjauhan antara satu dengan yang lainnya. Dengan kata lain, cara ini sering mengabaikan hak atau kepentingan anak. Sama juga dengan model lain yang membagi hak asuh anak oleh orang tua yang sudah bercerai setiap setengah minggu. ${ }^{15}$

\section{Hak Asuh Anak dalam Hukum Positif Indonesia}

Di dalam Pasal 41 Undang-undang No. 1 Tahun 1974 tentang Perkawinan disebutkan apabila putus perkawinan karena perceraian mempunyai akibat hukum terhadap anak, maka baik bapak atau ibu tetap berkewajiban memelihara dan mendidik anak-anaknya, semata-mata berdasarkan kepentingan anak, bilamana terjadi perselisihan mengenai penguasaan anak-anak, Pengadilan memberikan keputusannya.

Yang bertanggung jawab atas semua biaya pemeliharaan dan pendidikan yang diperlukan anak adalah bapak, bilamana bapak kenyataannya tidak dapat memberi kewajiban tersebut maka Pengadilan dapat menentukan bahwa ibu ikut memikul biaya tersebut. ${ }^{16}$

Sedang yang berkaitan dengan kewajiban orang tua terhadap anak diatur dalam Bab X mulai Pasal 45 - 49 UU Perkawinan. Pasal 45 UU Perkawinan mengatur bahwa kedua orang tua wajib memelihara dan mendidik anak-anak mereka sebaik-baiknya. Kewajiban orang tua tersebut berlaku sampai anak itu kawin atau dapat berdiri sendiri, dan kewajiban ini berlaku terus meskipun perkawinan antara kedua orang tua putus.

Sebaliknya dalam Pasal 46 UU Perkawinan, anak pun mempunyai kewajiban untuk menghormati orang tua dan mentaati kehendak mereka yang baik. Jika anak telah dewasa, maka ia wajib memelihara menurut kemampuannya, orang tua dan keluarga dalam garis lurus ke atas, apabila mereka itu memerlukan bantuannya.

Anak yang belum mencapai umur 18 tahun (delapan belas) tahun atau belum pernah melangsungkan perkawinan, berdasarkan Pasal 47 UU Perkawinan, ada di bawah kekuasaan orang tuanya selama merénía tidak dicabut dari kekuasaannya. Orang tua mewakili anak tersebut mengenai perbuatan hukum di dalam dan di luar Pengadilan. Selanjutnya Pasal 48 menyatakan orang tua tidak diperbolehkan memindahkan hak atau menggadaikan barang-barang tetap yang dimiliki anaknya yang belum berumur. 18 (delapanbelas) tahun atau belum melangsungkan perkawinan kecuali apabila kepentingan anak itu menghendakinya.

Pasal 49 UU Perkawinan mengatur pencabutan kekuasaan salah seorang atau kedua orang tua terhadap seorang anak atau lebih untuk waktu yang tertentu atas permintaan orang tua yang lain, keluarga anak dalam garis lurus ke atas dan saudara kandung yang telah dewasa atau pejabat yang berwenang, dengan keputusan Pengadilan dalam keadaan dua hal, pertama, ia sangat melalaikan kewajibannya terhadap anaknya; kedua, ia berkelakuan buruk sekali. Namun meskipun orang tua dicabut kekuasaannya,

${ }^{15}$ Rachel Emma Silverman and Michelle Hiqqins "Children and youth" dalam Wall Street Journäl, New York, 2003, hlm. 21.

${ }^{16}$ Hukumonline "Hukum Keluarga dan Waris Anak \& Perceraian" http://www.hukumonline.com/ klinik detail:asp?id=1883, diakses tanggal 10 Juni 2005. 
mereka masih tetap berkewajiban untuk memberi biaya pemeliharaan kepada anak tersebut.

Pasal-pasal tersebut secara umum telah berpihak kepada kemaslahatan atau kepentingan anak sekalipun keberpihakannya itu masih terbatas pada kepentingan material belum menyentuh kepentingan non-material. Baru setelah lahirnya Kompilasi Hukum Islam dua kepentingan tadi terakomodasi. ${ }^{17}$ Adapun pasal-pasal penting yang terkait dengan masalah tersebut adalah Pasal 105 dan 106.

Pasal 105 Kompilasi Hukum Islam mengatur dalam hal terjadi perceraian, maka: pertama, Pemeliharaan anak yang belum mumayyiz atau belum berumur 12 (dua belas) tahun adalah hak ibunya. Kedua, Pemeliharaan anak yang sudah mumayyiz diserahkan kepada anak untuk memilih di antara ayah dan ibunya śebagai pemegang hak pemeliharaannya; Ketiga, Biaya pemeliharaan di tanggung oleh ayah.

Dalam Pasal $106^{\prime}$ Kompilasi Hukum Islam dinyatakan orang tua berkewajiban merawat dan mengembangkan harta anaknya yang belum dewasa atau di-bawah pengampuan dan tidak diperbolehkan memindahkan atau menggàdaikan kecuali karena keperluan yang mendesak jika kepentingan dan kemaslahatan anak itu menghendaki atau sesuatu kenyataan yang tidak dapat dihindari lagi. Orang tua bertanggung jawab atas kerugian yang ditimbulkan karena kesalahan dan kelalaian dari kewajiban tersebut.

Dari ketentuan tersebut dapat disimpulkan bahwa pengaturan pemeliharaan anak dalam Kompilasi Hukum Islam meliputi pemeliharaan kepentingan mäterial dan nonmaterial. Lebih dari itu dalam ketentuan inipun dijelaskan tentang pembagian tugas yang harus dijalankan oleh kedua orang tua kendatipun mereka berpisah. Anak yang belum mumayyiz menjadi tanggungan ibunya, sedang biaya pemeliharaan menjadi tanggungan ayahnya.

Kompilasi Hukum Islam juga mengatur tentang batasan usia anak yang belum mumayyiz yaitu 12 (dua belas tahun). Dalam hal usia seperti ini, maka hak ibu untuk memeliharanya, sedangkan apabila usianya sudah lebih dari 12 (dua belas) tahun, maka ia dapat melilih antara 'bapak atau ibunya untuk bertindak sebagai pemeliharanya. ${ }^{18}$

\section{Simpulan}

Pada prinsipnya pengaturan tentarig hak pemeliharaan anak (hadhanah) baik yang terdapat dalam literatur figh klasik maupun dalam Undang-Undang Perkawinan serta Kompilasi Hukum Islam cenderung sama untuk berpendapat bahwa hak asuh anak adalah milik anak atau demi menjaga kepentingan anak. Perbedaannya hanya terletak pada pengaturan penentuan batas usia mumayyiz. Dalam literatur fiqh klasik seorang anak dikatakan mumayyiz apabila sudah menginjak usia 7 (tujuh) tahun untuk anak lakilaki dan 9 (sembilan) tahun untuk anak perempuan. Sedangkan Kompilasi Hukum Islam anak yang mumayyiz apabila sudah menginjak usia 12 (dua belas) tahun.

${ }^{17}$.Abdul Mannan, "Problematika Hadhanah dan Hübungannya dengan Praktik Hukum Acara di Peradilan Agama," Mimbar Hukum No. 49 THN. IX 2000, hlm. 69.

${ }^{18} \mathrm{H}$. Amiur Nuruddin dan Azhari Akmal Tagiran, Hukum Perdata Islam di Indonesia, Jakarta: Prenada Media, 2004, him. 303. 
Ketika terjadi perceraian di antara kedua orang tuanya demi menjaga kepentingan atau kemaslahatan anak, maka hak asuh itu diberikan pada ibu atau kerabat ibu, sedang yang terkait dengan pembiayaan menjadi tanggung jawab bapak. Apabila ternyata si bapak tidak dapat memenuhinya, maka ibu dapat ikut serta menanggung biaya pemeliharaan anak melalui suatu penetapan pengadilan.

Dalam kondisi tertentu ketika pelaksanaan hak ibu berbenturan dengan kepentingan anak, maka hak asuh berpindah ke tangan bapak. Misalnya ketika ibu harus bepergian jauh yang membahayakan keselamatan anak, atau si ibu dianggap kurang cakap memberikan kemaslahtan pada anaknya. Bahkan dalam Undang-Undang No. 1 Tahun 1974 lebih jelas lagi bahwa salah seorang kedua orang tua dapat dicabut hak pemeliharaannya untuk waktu tertentu atas permintaan orang tua yang lain, atau atas permintaan dari keluarga si anak dalam garis keturunan lurus ke atas dan saudara kandung yang telah dewasa atau pejabat yang berwenang (keputusan Pengadilan) apabila salah satu atau kedua orang tuanya apabila ia melaiaikan kewajibannya dan berkelakuan sangat buruk.

\section{Daftar Pustaka}

Abdul Azis Dahlan, Ensiklopedi Hukum Islam, Jakarta: Ikhtiar Baru, 1999.

Abdul Mannan, "Problematika Hadhanah dan Hubungannya dengan Parktik Hukum Acara Di Peraqdilan Agama, Mimbar Hukum, No. 49 THN. IX 2000.

Fathurrahman Djamil, "Pengkuan Anak Luar Nikah dan Akibat Hukumnya" dalam Chuzaimah T. Yanggo dan Hafiz
Anshar, Problematika Hukum Islam Kontemporer, Jakarta: Firdaus, 2002.

H. Amiur Nuruddin, dan Azhari Akmal Tagiran, Hukum. Perdata Islam di Indonesia, Jakarta: Prenada Media; 2004.

H. Badruzzaman Busyairi "Perceraian Halal tapi Dibenci Allah" http:/l muhajirien.or.id/mukaddimah/buletin/ mi edisi $110 . \mathrm{htm}$, diakses tanggal 10 juni 2005.

Kasus Azizah Shaik Ismail vs Fatimah Shaik Ismail "Judgment High Court of Malaya" www.ipsofactoJ.com/highcourt/ index.htm. Diakses tanggal 20 Maret 2005.

M. Yahya Harahap, Hukum Perkawinan Nasional, Medan: Zahir Trading, 1975.

M.M Nilam Widyarini, M.Si, "Derita Anak Korban Perceraian" http:II www.kompas.com/kesehatan/news/ 0503/18/110246.htm, Diakses tanggal 09 Juni 2005.

M.M Nilam Widyarini, M.Si, "Derita Anak Korban Perceraian" http:/l www.kompas.com/kesehatan/news/ 0503/18/110246.htm, Diakses tanggal 09 Juni 2005.

Munawir Sjadzali, "Peradilan Agama dan Kompilasi Hukum Isiam, dalam Dadan Muttaqin et.al (ed), Tata Hukum Indonesia, Yogyakarta: UIl Press, 1999.

Munira Salleh "Hak Penjagaan ke Atas Anak Selepas Perceraian: Tanggungjawab Siapa?" http://www.yadim.com.my/

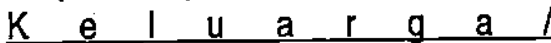
KeluargaFull.asp?KeluargalD $=78^{\text {"; }}$; diakses tanggal 10 Juni 2005

Rachel Emma Silverman and Michelle Hiqqins "Children and Youth", dalam Wall Street Journal, New York, 2003 
Sălahiuddin Wahidi, "Perkâuî̀inan, Àgàma, dan oj Nêgárä" http://wwwirepüblika.co.id/



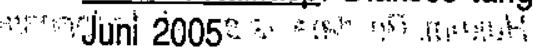

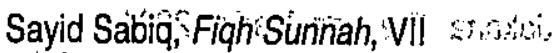
Watibah all=Zuhaily, Al-Figh al-tslamï Wa

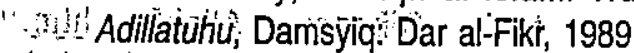
Wirjono Prodjodikoro; Hǔkumi Perkawinan di 01 Ifolndoriesià, Bandúng Surmur, 1960

Peraturan Perundang-Undangâñ : "itis

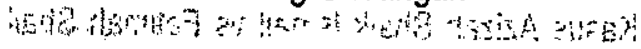

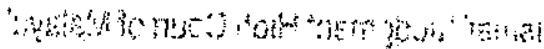

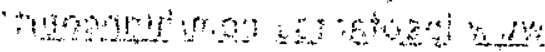

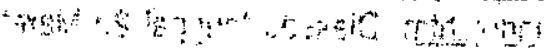

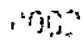

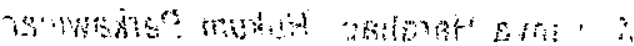

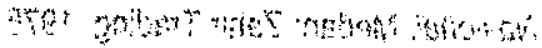

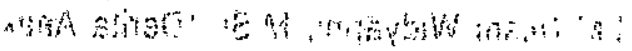

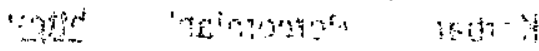
a


काष



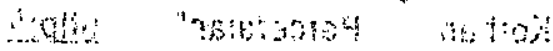


\%

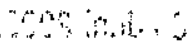

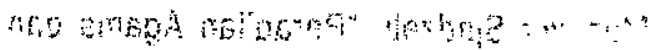

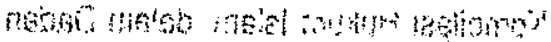

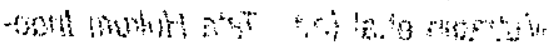

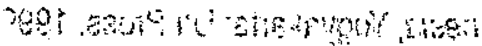



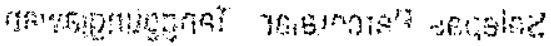



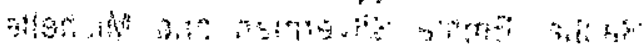

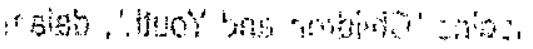

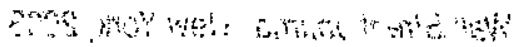

Undang-Undang"No. - 1MTahun 1974 teǹtang "a,

Kompilasi Hukum 'islam"in?

Hükumonline " "Huküm - Keluarga : dan

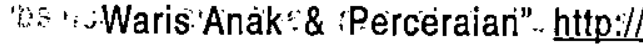
$\therefore$ W. W w huk u mo nil ine com top klinik detail asp? id=1883, diakses



Pikiran Rakyat;:"Doa untuk:Nizar:Ali"; 7.

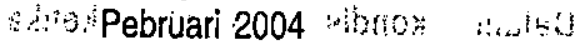

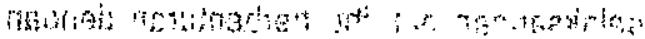

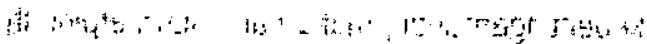

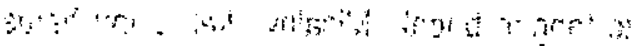

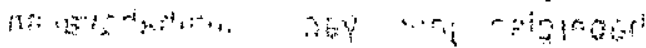

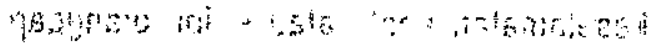





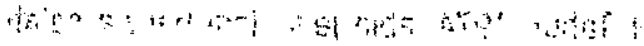



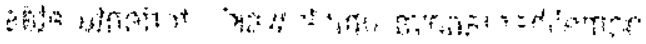



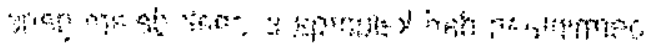

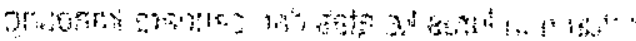

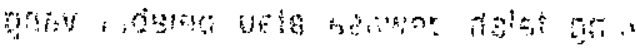

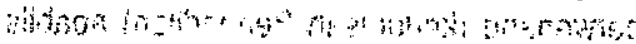

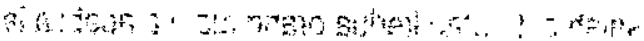


$\therefore$ a $a$ ane

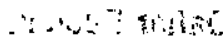

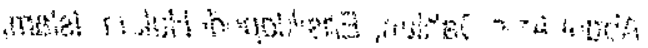
30 .

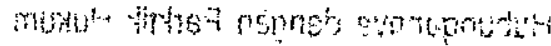

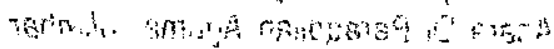
mo

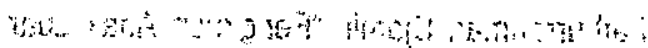
7.

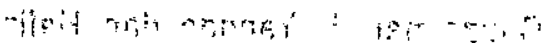

